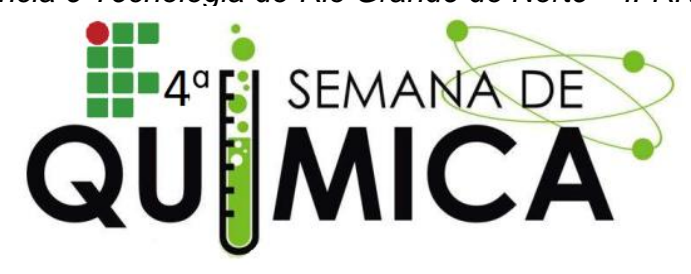

\title{
PRODUÇÃO DE CARVÃO ATIVADO A PARTIR DE MANDIOCA POR ATIVAÇÃO COM ZnCl 2
}

\author{
Araújo, C. A. C (IFRN), Lima, I. C. S. (IFRN), Penha, F. G. (IFRN)
}

Palavras Chave: carvão ativado, mandioca, adsorção.

\section{INTRODUÇÃO}

O carvão ativado consiste em um material de carbono com uma porosidade bastante desenvolvida, com capacidade de coletar seletivamente gases, líquidos ou impurezas no interior dos seus poros ${ }^{1}$. O trabalho tem por objetivo a produção de carvão ativado a partir da mandioca por ativação química com $\mathrm{ZnCl}_{2}$.

\section{METODOLOGIA}

A mandioca cortada em pedaços foi impregnada com $\mathrm{ZnCl}_{2}$ numa proporção em massa 1,00:0,50 precursor/ativante. Após, realizou-se a pirólise, que ocorreu num forno mufla a 500 C durante 30 minutos. O carvão obtido foi lavado com $\mathrm{HCl} 6 \mathrm{M}$ e água destilada e seco em estufa. Para avaliar a capacidade de adsorção, isotermas foram construídas utilizando azul de metileno como molécula modelo e comparado a um carvão comercial. A quantificação foi determinada por UV-vis. a temperatura ambiente. Todos os procedimentos foram realizados nos laboratórios do IFRN-Nova Cruz.

\section{RESULTADOS E DISCUSSÕES}

A Figura 1 mostra imagens do precursor (mandioca) e do carvão ativado produzido. A Figura 2 mostra as isotermas de adsorção para o carvão ativado produzido a partir da mandioca comparado com a de um carvão comercial.

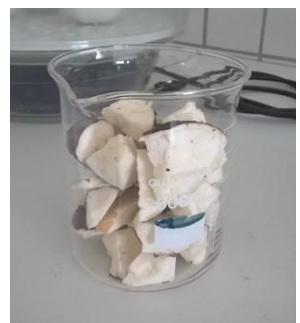

(a)

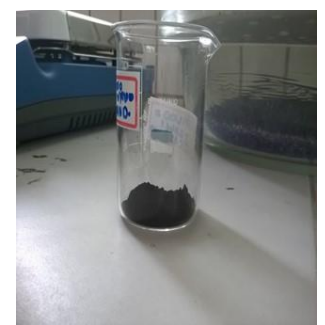

(b)
Figura 1 - (a) precursor (mandioca) (b) carvão ativado preparado.

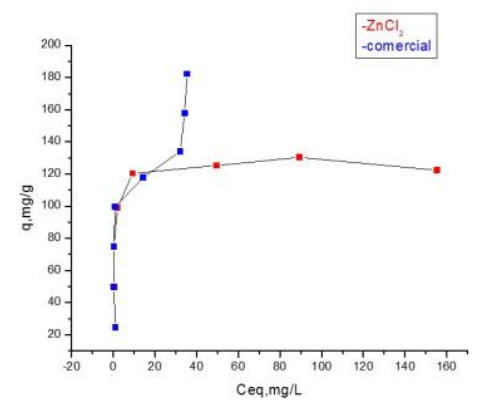

Figura 2 - Isotermas de adsorção para o carvão preparado da mandioca e para um carvão comercial, $\mathrm{T}=$ ambiente $25^{\circ} \mathrm{C}$.

\section{CONCLUSÃO}

A capacidade de adsorção para o carvão ativado preparado da mandioca foi semelhante ao do carvão comercial, atingindo uma saturação de aproximadamente $130 \mathrm{mg} / \mathrm{g}$. Porém, as formas das isotermas diferentes indicam maior micro porosidade ao carvão da mandioca.

\section{REFERÊNCIAS}

${ }^{1}$ Pezoti Jr., O.; et al; Journal of Ind. Eng. Chem. 20, 4401-4407, 2014. 